\title{
Employer's Liability for Damages Caused to the Thidr Parties by their Eployees
}

\section{Anita Bardhi Phd Candidate}

\author{
European University of Tirana , Faculty of Law, Tirana/Albania \\ bardhi.anita@gmail.com
}

\section{Doi:10.5901/mjss.2016.v7n1s1p423}

\begin{abstract}
In this paper will treat the responsibility of the employer against the employee for damages caused to third parties, as one of the types of non- contractual damage, in some European countries legislations, as well as comparisons between them. How is treated responsibility of the employer over the years, which are the innovations of the legislations for this responsibility for damage caused by the employee. This is a paper which highlights cases in which employers are charged with the responsibility for damages caused by their employers during the employment relationship, will analyze all the conditions or criteria that must be met in order that employers be charged with legal responsibility and to answer before the law and against the injured party by his employers, because employers can not be charged with responsibility, for any damage caused by their employers, limiting only to the fact that between them exists a contractual agreement through which arises employment relationship. In which case the employer may avoid liability for damages caused by their employers, Which are the conditions sets by different legislation for avoiding this kind of responsibility? Is there a such possibility or in every case the employer will be charged with responsibility for the damages caused by their employers during employment relationship? Most of the legislation determine that the employer discharged from liability if he proves that it has taken all necessary measures to avoid the damage but could not prevent it, how will prove this fact in practice?
\end{abstract}

Keywords: employer, employee, non-contractual damage, responsibility, guilt.

\section{Introduction}

The work relationship is a very old relationship which closely relates to other areas in which is based and developed the human society. In this theme will make firstly an analysis which of the work relationship subjects and specifically the employer or employee will be charged with responsibility in the event of a damage caused to third parties by the employee during the employment relationship by the Albanian legislation, then It will be analyzed the way of dealing with this responsibility as part of the contractual damage in the legislation of developed western European countries.

Given the historical perspective, until the end of the nineteenth century, the legal doctrine of most industrialized Countries, has been the dominant principle of fault liability. After this period the industry and trade relations had a qualitative leap that showed an exception to the general rule of fault liability. Up to that time fault was considered as main and only cause that could allow the injured party to transfer its loss, causer of the contractual damage (Gade \& Toutges 1983).

Here we will handle the damages that cause an employee while performing his job for which the employer bears responsibility. Economic growth, industrialization, the growth of trade and economic activities generally made necessary the elaboration of a system such that is allowed for a person or an economic entity to use the services of other persons for its own economic interests. Since these persons or entities benefit from the services employers of those employees working for them, it was considered as natural for them to be responsible for the actions considered harmful to their workers ( Greenwood \& Johnson 1985). It also for the fact that they can control the actions of the employees themselves and thus attenuating the behavior that can be the cause of the damage or causing some damage to third persons outside the employment possible relationship.

In 1911 the Court of Appeals of New York, refused to put the responsibility on the employer for the accident that had caused his workers in the factory (Harris 1987).

According to that Court the Constitution forbid that a citizen penalized or placed under the responsibility if he had not violated a legal provision or action was carried directly on the fault.

This reasoning seems to support the natural right according to which the person held responsible only for actions committed with guilt. This point of view is considered unacceptable today, in all modern legal systems; the cost of an industrial accident is transferred in a way though to another employer, which in turn has the possibility to pass this cost to 
the final price of the product by passing this cost to the entire company. 1999).

For the above George Lloyd says: "The cost of a product should include the blood of an employee" (Zweigert

We have two directions in the doctrine loading employer liability for damages caused by their employees and illegal actions during the work relationship.

In the first case we will mention the case:

The employer is considered responsible for the harmful actions of his worker but not on his fault but on the fault of its employees, this is a position that is held in almost the majority of legal systems in the world.

While the second position has to do with the attitude that holds the German Civil Code (Applicable) which is different from the first.

According to this attitude the responsibility of the employer is based on his fault. The employer is considered guilty of choosing the employees or the supervision of its activities. This second approach is due to the fact that in the nineteenth century, Pandektistet considered that (culpa in eligendo) fault for the election of the worker's, was the only reason that was known from Roman law to make an employer liable for the harmful actions of employee thereof. This approach can be acceptable in some cases but cannot be extracted from it a doctrine (Lobed 1985).

One of the reasons for non-recognition of this responsibility in the legislation of this country is perhaps a fear that uploading the responsibility of the employer in this case Whole enterprise and company business, this fact would lead to weakening of small business but also the medium.

Jhering says about this: "is not causing damage that makes someone to compensate the damage, but his fault for this bull. This is as clear as the very fact that it is not the burning light, but oxygen that is in the air"(Nuni En el 2008)

But is know very clearly now that Germany is one of the countries with the most developed industry in Europe but also elsewhere, where cases of occupational accidents are still frequent so that a large industrial development but also dangerous for the role of employees generally with drastic consequences for their lives Notwithstanding the goods and benefits of performing the work for themselves employees and business development for employers or industry in general for the state itself.

A major development of the industry will have consequences for economic growth of the employer but also imposes greater attention to the implementation and observance of safety measures at work employee, which are the primary rule to protect them, and yet would not be appropriate to employee charged with responsibility for actions caused by him at work because at this development level is much higher than at the time when the industry was not so developed and actions involved in the work of employees did not posed this much of risk(Galgano 1999) .

So Germany has amended its legislation already in this position where predicted that liability for damages caused by the employee during their work will fall on themselves, by recognizing currently that will be responsible for works incurred at the working time in a work relationship is itself the employer who has the ability and capacity actually to cover and compensate for the damage caused.

So to make a summary of everything that was quoted above, today's legislation of almost the majority of developed countries the responsibility for damage caused by employee in a working relationship falls on the employer who employs him, since he is obliged to respect and create its own employees conditions to be safe at work.

Furthermore the employer is obliged to decide coercive tools for their employee to implement and respect all actions which are part of legislation for the safety at work by concrete activity.

Thus making it possible to avoid as many accidents in the framework of the protection of its employees, their life and health but also defending one of the basic reasons of the creation of this relationship, and protect their business from any harm if an economic or prestige and moral for the business itself, because it should be noted that nowadays one of the main reasons for the success of businesses around the world is goodwill or good reputation (Satcher, \& Hendren 1999)

This is so true as I would say that the great damage caused by an employer in the event of accidents or in whatever form be it, is moral damage than the economic and especially for large companies with well-known international name and media television or any form whatsoever.

But the employer's responsibility for damage caused by its employee cannot be naturally unlimited, so not necessarily in every case and every employer will be charged with the responsibility for any damage caused by its employee and at any time or in every circumstance to his cause (Lobed 1985).

In jurisprudence there are certain conditions or criteria that limit and orient the justice organs in loading employers' liability for the damage caused by the employee.

Here we are dealing with some of the conditions of responsibility from the employer in which the damage caused can be charging him with legal responsibility. 


\section{Employer Responsibility According to the Albanian Legislation}

To be in terms of the employer's liability for extra contractor damage caused by employee should be fulfilled these conditions expressly provided in Article 618 of the Civil Code of Republic of Albania

"The employer is responsible for the damage caused to third parties for the fault of the employees who are at his service during the possible relationship with the exercise of the duties entrusted to him. Legal person is responsible for the damage caused by its organs in carrying out their duties ${ }^{1 "}$

From the above-cited article are shown all the conditions that must be present in a working relationship so that the employer can be charged with the responsibility for damages caused to third parties by their employers, as follows:

1. Making an analysis of the content of this article shows that the first criterion and most important is that the existence of the relationship between employers and employees working in its service (Nuni en el 2008), between these two entities should exist a contractual agreement regarding the legislation in force in the country in which the seat is located, employers or particular cases under the provisions wire legislation working for this legal action, otherwise if the person who performs a job in this case the employee be working for another person employer without a contractual agreement between them we cannot qualify as working relationships and none can legally affected by legal obligations to this specific relationship is. But we are in terms of what is called working illegally and in this case these subjects will be prosecuted by law.

2. Secondly, another very important element turns out to be for the employer in order to be charged with the responsibility for the actions of its employee must certainly that employee at the time to cause damage to third parties should be performing only tasks for which he is charged by his employer then must perform only those actions for which it is created and continues to work relationship between its subjects(Nuni 2008), or employee be performing an action which is directly linked to the subject activity of the employment contract.

If the employee is performing an action which does not fulfill the employee contractual obligations and nor asked by the employer as a certified additional work this supplement by a contract or a statement through which employee is authorized to perform these acts outside what is forecasted in the contract of employment, then according to the law he will hold himself responsible for the damage caused in this case. In Albanian practice are rare cases in which the employer authorize their employees to perform any additional actions other than those which are provided for in the contract, for example as a supplement contract or a statements from, or authorization whatever it is, but this is a among the most difficult cases and safe for worker protection by the law due to not having a legal document that he can present as evidence in court or if the third person and himself who has been causing a damage.

3. Thirdly, an important element has to do with the time in which the illegal act caused in the injury of the third parties, contractual damage caused to third parties by an employee must be performed during the time in which employee is in the relationship of Work also will therefore be charged with the responsibility of the employer for the damage caused to third parties by the employee only if at the time caused damage employee was working at the normal time allowed by his employer. If the employee after the work is finished or is coming to work or in any situation that may occur it but working hours, and happens to cause a damage to someone else work out then logically possible relationship that this will not be included in the range of those cases where the employer will necessarily be charged with the responsibility for the damage outsource caused by his employee. This case will be considered necessarily outsource but the responsibility falls totally on the person who caused the damage, then in this case the employee will hold himself responsible for the damage that has caused also someone else or is in a working relationship this case does not constitutes to put responsibly on someone else (Zweiger and Kotz 1999).

Based on the above, we reach the conclusion that the responsibility of the employer is responsible to blame, because the employer is the person charged with the obligation to take all measures under domestic and international law recognized by domestic legislation to avoid performance these illegal actions by employees.

Although it sounds a bit absurd to think that if a person has had no direct connection with the action committed by someone else, however, will be considered legally responsible and will respond before justice authorities for the damage caused by another person in this case the employee.

Generally, jurisprudence has more subjective thoughts on almost every case are endless and as it deems someone a case does not judge someone else but for the case which we are discussing in this paper actually employer should be charged with liability for damage caused by his own employee and this responsibility also rightly considered

${ }^{1}$ Civil Code of the Republic of Albania 
guilty responsibilities after work during the possible relationship that the latter is obliged to observe not only supervising the safety of workers but also of persons who may be affected indirectly by the exercise of the activity of the employer which is licensed or has the legal right to exercise them (Sutton 1999)

The employer is obliged to create as appropriate as possible conditions especially in the case of hazardous activities which require a special care and attention for themselves as health workers and their lives but also for third parties who may be affected or risk of this activity directly or indirectly whatsoever, to employer is attributable responsibility for safety measures and measures to avoid the risk also.

Employer will be discharged from liability only if he will prove to the competent authorities that he himself has taken all possible measures to prevent the occurrence of a specific damage or some damage of his employee, but however the damage was caused, for reasons which are not directly related to the operations of the employer or the fact that he did not take measure for avoiding this risk during the employment possible relationship.

So in this way we conclude that an employer to be charged with the responsibility for actions caused by its own employees need to be damage caused by its employee during the employment relationship with the employer not to have made any attempt to avoid this damage, for example can consider from the non creation of favorable conditions in the work environment to not taking his measures for safety at work.

And the employer is discharge from liability for actions of its employees, if he proves that he has taken all necessary measurements for the avoidance of any kind of possible damage that may be caused during the possible work relationship by his employers but despite real effort the random damage is caused, so that the Feasibility or probability not happen bull was not dependent to care or good actions that should have tackled the employer.

\section{How Various Jurisdictions Treat the Employer's Liability for Damages Caused to Third Parties by their Employers}

\subsection{According to the Italian Legislation}

In Article 2049 of the Italian Civil Code stipulates that "employers must answer for damages caused by their subordinates, on behalf of the responsibility of others (employers) regarding the risk of taking objectively at the time that employees become part of the company", to perform the activities set out in the contractual relationship and that belong to them, is not about the responsibility that derives from the fact that employers have not chosen appropriately or adequately the employee.

Based on the above, in the Italian legislation uploading employer liability apparently is not intended only for cases when the employer did not perform the actions necessary or indispensable which allow or may avoid causing damages from his employers.

Italian legislation does not limit employer liability only in the performance or not of all actions necessary and essential for the safety of workers or for their supervision in order to avoid potential harm almost every caused by employees(Francesco 1999), but under this legislation employer is charged with legal responsibility for the actions of their subordinates caused by employers during the possible work relationship.

So based on this legislation to employer is attributed legal responsibility for its employees actions from the moment that he creates a working relationship with them, so the risk to be charged with responsibility for the actions of third parties caused by his subordinates comes from the creation of the possible employment relationship. With the creation of this relationship employer assumes to be charged with the responsibility for the actions of its employees for the damages that may be causing the latter others with their actions in carrying out the activities foreseen in the contractual relationship and that belong to them (Zweigert \& Kotz 1999).

The above paragraph shows that the Italian legislation which are dealing with the topic of employer liability for the actions of its employees is not unconditional, thus the employer will be liable for damages caused by outsource its employees but only in those cases where damage is caused to third parties during the possible relationship of work, then the first condition has to do with the fact that the employee should be during working hours or during the execution of tasks and activities which obliged him under the employment contract with the employer .

The second condition is that the employee should be performing only those tasks which are granted to him on the basis of possible work relationship, so if damage happens when employers are doing the tasks that belongs to them.

And it should be noted that compared with the Albanian legislation on the issue of employer responsibility on employees to self is not conditioned by the fact that the employer has met all safety measures in work or work correctly applied all legal obligations for supervising of employs during the possible employment relationship (Semini 2006).

But normally this issue is not totally unlimited for the fact that not every damage that can be caused by their 
employees will be due to be loaded the employer with liability, because it would be absurd, for example, to think when an employee commits an illegal act with his desire, this is a case that has to do with the subject himself and it is the court which has the duty to determine and evaluate that on which person will fall the responsibility charge.

\subsection{How French legislation treats this issue}

With regard to the French legislation, in the Articles 1434,12087,12088 of the Frech Civil Code it provides that if a person in this case (the employer) permits or orders another person to perform certain actions on his behalf is required to compensate the damage caused to the guilt of the person (employee) during carrying out its functions.

If the victim can prove that an employee has committed an offense and that offense is committed in the framework of his duties, the employer is presumed responsible for the damage caused.

But even in this legislation it is the responsibility of the employer not unconditional.

\subsection{A general analysis}

Based on the French legislation the employer is presumed responsible for the fault of their employees and is responsible to compensate the victim in case it proves that:

1. The person who has caused the damage is employee of the employer against whom the judicial process will be starting, and it verified through the existence of possible employment relationship between them, this is related to the fact that if the employer is actually a working relationship is obliged to oversee and manage its employee's actions. To prove that his employee at the time of causing the damage had no fault the behavior and actions of the latter will be compared with those of an employee who is good conscience and in one case the same will react in the same way as the employee in proceedings.

2. If the employee has been performing only those duties that have been entrusted to him by the employer under the employment contract or actions that are necessary for the nature of work.

3. With regard to ascertaining or proving the existence of possible relationship of work, it is not necessarily to exist a contractual agreement between the parties, but this relationship can be proved even by orders that person (the employer) gives someone else (employee) for their implementation, so therefore he acts on behalf of someone else but making those actions which have been designated by him against a remuneration, it is sufficient fact for the Court to consider them as employees.

\section{Conclusions}

In conclusion we can say that employer rightly is considered liable for damages caused to third parties by their employers, this for some legitimate reasons and very logical:

First, the employer at the time that enters into a working relationship with its employee is normally obliged to take all necessary measures to ensure its own employees all conditions which are crucial for safety at work either for employees themselves even for the third parties outside this relationship.

Secondly, the employer is obliged to undertake all actions necessary for the supervision of the work of employees in order to prevent damage caused to anybody.

Third, on despite the aforementioned cases in the creation of the work relationship the employer I think that necessarily should be liable for as long as the employee is performing an action for employers in terms and conditions and the time specified by the employer, so if someone performs an action ordered by someone else (the employer) and within the framework set by him, then necessarily responsible will be that person for which they are being carried out these works and not employee who is simply implementing what orders the employer. But this reasoning is always related to those cases in which it is confirmed that the employee actually did not act with fault, this means that the employee has acted in the same way as anyone else can with full legal capacity and to operate in the same conditions.

\section{References}

Civil Code of the Republic of Albania

Applicable French Civil Code

Applicable Italian Civil Code

Spinak Jane M.,(2014) "Judicial Leadership in family court: A cautionary tale", Fall 2014/ Volume Leadership in family corut: A cautionary 
tale", Fall 2014/ Volume 10/ Issue 1 Tennessee Journal of Law and policy 47.

Semini Marjana, (2006)“E drejta e Detyrimeve pjesa e pergjithshme (The Law of Obligations general part)", Tirana

Galgano Francesco, (1999 )"E drejta private (Privat Law)" Luarasi, Tirana,

Adrian Nuni en el, 2008, "E drejta e detyrimeve Pjesa e pergjithshme (The Law of Obligations general part)", Tirana

Gade, E.. \& Toutges, G. (1983). Employers' attitudes toward hiring epileptics: Implications, for job placement. Rehabilitation Conseling Buletin, 26(5). 353-356

Greenwood, R \& Johnson V.A (1985), Employer concerns regarding workers with disabilities. Hot Springs: Arkansas University, Arkansas Rehabilitation and Research Center.

Harris and Associates (1987), The ICD survey II: Employing disabled Americans: A nationwide survey of 920 Employers, New York: Author

Holmes. D.A \& Mc Williams, J.H (1981). Employers' attitudes toward hiring epileptics, Journal of Rehabilitation

Lobed H.Z (1985), Employing the disables is good business, Industri Week, 227(2),14

Martin T.N \& Vieceli L. (1988), The business of rehabilitation placement: What to understand about private employers before approaching them, Journal of Rehabilitation

Satcher, J.F \& Hendren G.R (1991). Acceptance of the Americans with Disabilities Act of 1990 by persons preparing to enter the business field, Journal of Applied Rehabilitation Counseling.

Zweigert. K and Kotz H. (1999) An Introduction to Comparative Law (Second editions)

Delory Anne Marie, (1987)"Joint Legal Custody: A revision to Patriarchal Power" 